\title{
Survei Status Gizi (IMT), Kebugaran Jasmani Siswa SMPN 1 Marioriawa Kabupaten Soppeng Provinsi Sulawesi Selatan
}

\author{
Sudirman Burhanuddin \\ Correspondence: Fakultas Ilmu Keolahragaan, Universitas Negeri \\ Makassar, Makassar, Indonesia \\ E-mail: sudirman_burhanuddin@yahoo.co.id
}

\begin{abstract}
Abstrak
Penelitian deskriptif ini bertujuan untuk mengetahui status gizi dan kebugaran jasmani siswa SMPN 1 Marioriawa Kabupaten Soppeng Propinsi Sulawesi Selatan tahun ajaran 2016/2017. Sampel dalam penelitian ini berjumlah 30 orang. Teknik penentuan sampel adalah dengan cara simple random sampling. Teknik analisis data yang digunakan adalah analisis deskriptif dan analisis deskriptif frekuensi krostab. Hasil penelitian menunjukkan bahwa status gizi siswa SMPN 1 Marioriawa dalam kategori baik dalam ambang normal dan kebugaran jasmani siswa SMPN 1 Marioriawa dalam kategori baik atau sebesar 46,67\%.
\end{abstract}

\section{Kata Kunci: Status Gizi, Kebugaran Jasmani}

\section{Pendahuluan}

Pendidikan jasmani pada dasarnya merupakan bagian integral dari sistem pendidikan secara keseluruhan. Oleh karena itu, pelaksanaan pendidikan jasmani harus diarahkan pada pencapaian tujuan tersebut. Tujuan pendidikan jasmani bukan hanya mengembangkan ranah jasmani, tetapi juga mengembangkan aspek kesehatan, kebugaran jasmani, keterampilan berfikir kritis, stabilitas emosional, keterampilan sosial, penalaran dan tindakan moral melalui kegiatan aktivitas jasmani dan olahraga. Pendidikan jasmani merupakan media untuk mendorong perkembangan motorik, kemampuan fisik, pengetahuan dan penalaran, penghayatan nilai-nilai (sikap, mental, emosional, spiritual dan sosial) serta pembiasan pola hidup sehat yang bermuara untuk merangsang pertumbuhan dan perkembangan yang seimbang.

Pendidikan jasmani memiliki peran yang sangat penting dalam mengintensifkan penyelenggaraan pendidikan sebagai suatu proses pembinaan manusia yang berlangsung seumur hidup. Pendidikan jasmani memberikan kesempatan pada siswa untuk terlibat langsung dalam aneka pengalaman belajar melalui aktivitas jasmani, bermain, dan berolahraga yang dilakukan secara sistematis, terarah dan terencana. Pembekalan pengalaman belajar itu diarahkan untuk membina, sekaligus membentuk gaya hidup sehat dan aktif sepanjang hayat.

Adapun ruang lingkup pendidikan jasmani meliputi aspek permainan dan olahraga, aktivitas pengembangan, uji diri / senam, aktivitas ritmik, akuatik 
(aktivitas air) dan pendidikan luar kelas. Kesegaran jasmani siswa di sekolah harus dapat dipertahankan dan ditingkatkan melalui proses pendidikan jasmani.

Pembelajaran pendidikan jasmani pada dasarnya membentuk karakteristik siswa sihingga dalam kehidupan sehari - hari terlihat sehat dan bugar. Berdasarkan pada permasalahan diatas maka penelitian ini diarahkan pada status gizi dan kebugaran jasmani siswa SMP Negeri 1 Marioriawa Kabupaten Soppeng,

Pada umumnya setiap manusia ingin melakukan semua aktivitas tanpa merasakan suatu kelelahan yang diakibatkan oleh aktivitasnya. Tapi faktanya, olahraga yang seharusnya mampu mengatasi hal tersebut kurang di optimalkan oleh masyarakat. Padahal olahraga mampu memberikan kontribusi positif untuk kesehatan dan kesegaran tubuh. Selain itu dapat mengembangkan potensi-potensi aktivitas manusia yang berupa sikap, tindak dan karya yang pada hakekatnya akan meningkatkan kesegaran jasmani, karena kesegaran jasmani berperan membentuk generasi muda yang sehat, kuat dan potensial sebagai tenaga dalam pembangunan indonesia.

Kesegaran jasmani sering disebut juga dengan istilah kebugaran jasmani (psycal fitness). Semua orang melakukan tingkat kesegaran jasmani tertentu sesuai dengan fungsinya dalam proses kehidupan. Untuk mengembangkan kesanggupan dan kemampuannya.

Siswa yang memiliki tingkat kesegaran jasmani yang baik akan mampu melakukan semua aktivitasnya dengan baik. Berbeda dengan siswa yang tidak memiliki kesegaran jasmani, siswa tersebut akan mudah mengalami kelelahan dan konsentrasi yang tidak fokus. Hal ini tentu membuktikan bahwa kesegaran jasmani tentu dibutuhkan dalam hidup. Selain dari kesegaran jasmani, gizi juga ikut berpengaruh terhadap aktivitas seseorang. Karena status gizi merupakan ukuran keberhasilan dalam pemenuhan nutrisi. Dengan demikian ingin mengetahui situasi tersebut melalui kajian lebih dalam dengan melakukan penelitian dengan judul "Analisis status gizi dan kebugaran jasmani siswa SMP Negeri 1 Marioriawa Kabupaten Soppeng Provinsi Sulawesi Selatan”.

Berdasar dari latar belakang, maka permasalahan dalam penelitian ini dapat dirumuskan sebagai berikut: (1) Dimensi konteks, yang terdiri dari: 1). Bagaimanakah status gizi siswa SMP Negeri 1 Marioriawa Kabupaten Soppeng, 2) bagaimanakah kebugaran jasmani siswa SMP Negeri 1 Marioriawa Kabupaten Soppeng

\section{Pustaka}

Kebugaran jasmani dikenal dengan istilah asing "physical fitness." Physical berarti badan atau tubuh sedangkan fitness berarti segar. Jadi yang dimaksud dengan physical fitness (kebugaran jasmani) yaitu badan yang sehat dan segar. Pengertian kebugaran jasmani dipandang sebagi suatu konsep yang mempunyai ruang lingkup yang cukup luas. Oleh karena itu, para ahli mendefenisikan sesuai dengan sudut pandang keahlian. Misalnya, dari segi kedokteran lebih menitik beratkan pada kemampuan jantung dan paru-paru. Dari

PJKR_

http://jurnal.unimed.ac.id/2012/index.php/jpehr/index 
bidang olahraga lebih menitik beratkan pada keberhasilan melakukan aktifitas fisik tanpa menimbulkan kelelahan yang berarti.

Menurut Mutohir dan Maksum (2007:51) kebugaran jasmani adalah kesanggupan tubuh untuk melakukan aktivitas tanpa mengalami kelelahan yang berarti. Orang yang bugar berarti ia tidak gampang lelah dan capek. Ia dapat mengerjakan pekerjaan sehari-hari secara optimal, tidak malas atau bahkan berhenti sebelum waktunya

Kebugaran anak-anak usia sekolah juga sangat penting, terutama kebugaran dalam mendukung motivasi belajar siswa. Secara logika, apabila seorang siswa sakit sulit untuk berkonsentrasi belajar. Dengan demikian kebugaran secara signifikan tidak langsung memiliki kontribusi terhadap prestasi belajar, namun anak pada usia sekolah mempunyai potensi yang sangat besar untuk dioptimalkan segala aspek perkembangannya, termasuk aspek fisik. Artinya aspek fisik sebagai perkembangan dari unsur kematangan dan pengendalian gerak tubuh. Terdapat hubungan yang saling mempengaruhi antara hubungan tubuh, keterampilan gerak, dan kontrol gerak, keterampilan gerak anak tidak akan berkembang tanpa adanya kematangan kontrol gerak. Kontrol gerak tidak akan optimal tanpa kebugaran tubuh.

Menurut Nurhasan (205:17) kebugaran jasmani merupakan kondisi tubuh seseorang yang mempunyai peranan penting dalam kegiatan atau aktivitas seharihari. Kesegaran jasmani juga diartikan bahwa kemampuan melakukan kegiatan sehari-hari dengan penuh vitalitas dan kesiagaan tanpa mengalami kelelahan yang begitu berarti dan masih cukup energi untuk beraktivitas pada waktu senggang dan menghadapi hal-hal yang bersifat darurat.

Kebugaran jasmani menurut Depkes RI (2009:9) adalah kemampuan tubuh seseorang untuk melakukan pekerjaan sehari-hari dalam jangka waktu relative lama tanpa menimbulkan kelelahan yang berarti

Seseorang yang memiliki tingkat kebugaran jasmani akan dapat melakukan pekerjaannya dengan baik tanpa mengalami kelelahan yang berarti, serta tubuhnya tetap segar ketika berhenti bekerja dan pada saat istirahat. Sebaliknya tingkat kebugaran jasmani yang rendah merupakan kendala dalam melaksanakan pekerjaannya.

Menurut Mc Laren yang dikutip Suharjo, (1989:27) mengemukakan bahwa status gizi merupakan hasil keseimbangan antara zat-zat gizi yang masuk dalam tubuh dan penggunaanya. (Soekirman, 2000: 6) mengemukakan bahwa status gizi adalah keadaan kesehatan akibat interaksi antara makanan, tubuh manusia dan lingkungan hidup manusia.

Status Gizi Anak adalah keadaan kesehatan anak yang ditentukan oleh derajat kebutuhan fisik energi dan zat-zat gizi lain yang diperoleh dari pangan dan makanan yang dampak fisiknya diukur secara antropometri dan dikategorikan berdasarkan standar baku WHO-NCHS dengan indeks BB/U, TB/U dan BB/TB (Suharjo, 1996: 102).

Menurut Almatsier status nutrisi adalah keadaan tubuh sebagai akibat konsumsi makanan dan penggunaan zat-zat gizi (Fatmah,25: 2011). Secara umum bentuk kelainan gizi digolongkan menjadi dua yaitu: 
- Overnutrition (kelebihan gizi) adalah suatu keadaan tubuh akibat mengkonsumsi zat-zat gizi tertentu melebihi kebutuhan tubuh dalam waktu yang relative lama.

- Undernutrition adalah keadaan tubuh yang disebabkan olah asupan zat gizi sehari-hari yang kurang tidak dapat memenuhi kebutuhan tubuh.

Baik buruknya gizi seseorang sangat bergantung pada kualitas dan kuantitas makanan yang dimakan, dalam hal ini gizi sangat berpengaruh dalam kesehatan jasmani. Jika seseorang mempunyai status gizi yang buruk maka kesehatan jasmaninya juga akan buruk begitu juga dengan kebugaran jasmaninya.

Dari beberapa pendapat di atas penulis menyimpulkan tentang status gizi, status gizi adalah ekspresi dari keadaan keseimbangan dalam bentuk nilai tertentu atau dapat dikatakan bahwa status gizi merupakan indikator baik buruknya penyedian makanan sehari-hari. Status gizi yang baik diperlukan untuk mempertahankan derajat kebugaran dan kesehatan, membantu pertumbuhan bagi pertumbuhan manusia serta menunjang perestasi olahraga.

\section{Metode}

Metode yang digunakan dalam penelitian ini ini menggunakan metode survei. Teknik analisis data yang digunakan adalah analisis deskriptif frekuensi menguji status gizi dan kebugaran jasmani siswa SMP Negeri 1 Marioriawa Kabupaten Soppeng Propinsi Sulawesi Selatan.

Sampel penelitian ini adalah siswa laki - laki SMP Negeri 1 Marioriawa Kabupaten Soppeng tahun ajaran 2016/2017 kelas VIII berjumlah 30 sampel penelitian dini dilaksanakan dari tanggal $01-30$ Mei 2017. Dalam mengumpulkan data yang dibutuhkan dalam penelitian ini, peneliti menggunakan teknik pengumpulan data berupa instrumen tes yang ada. Teknik pengumpulan data tersebut dapat diuraikan sebagai berikut:

Tabel 1 Bentuk Tes Kebugaran jasmani (Kemdiknas 2010)

\begin{tabular}{|c|c|}
\hline Faktor - faktor & Item penilaian \\
\hline $\begin{array}{l}\text { 1. Kekuatan dan daya tahan otot-otot } \\
\text { lengan dan bahu }\end{array}$ & $\begin{array}{l}\text { 1. Pull Ups (Bergantung angkat } \\
\text { badan) untuk putera. }\end{array}$ \\
\hline 2. Daya tahan otot-otot perut & $\begin{array}{l}\text { 2. Sit ups (Baring duduk) } 60 \\
\text { detik. }\end{array}$ \\
\hline 3. Power tungkai & 3. Loncat tegak. \\
\hline 4. Kecepatan lari & $\begin{array}{l}\text { 4. Lari cepat } 50 \text { yard } \\
\text { (45,74meter). }\end{array}$ \\
\hline $\begin{array}{l}\text { 5. Daya tahan jantung, perdaran darah } \\
\text { dan pernafasan }\end{array}$ & 5. Lari jauh Jarak 1200 meter \\
\hline
\end{tabular}

PJKR_

http://jurnal.unimed.ac.id/2012/index.php/jpehr/index 
Tabel 2. Norma Tes Kesegaran Jasmani Indonesia (Kemdiknas: 2010)

\begin{tabular}{|l|l|l|}
\hline No & \multicolumn{1}{|c|}{ Jumlah nilai } & \multicolumn{1}{c|}{ Klasifikasi } \\
\hline 1 & $22-25$ & Baik Sekali (BS) \\
\hline 2 & $18-21$ & Baik (B) \\
\hline 3 & $14-17$ & Sedang (S) \\
\hline 4 & $10-13$ & Kurang (K) \\
\hline 5 & $5-9$ & Kurang Sekali (KS) \\
\hline
\end{tabular}

Selanjutnya untuk status gizi menurut keputusan mentri Kesehatan RI No.1995/Menkes/SK/XII/2010, Pengukuran IMT dapat dilakukan pada anak mulai usia 5-18 tahun atau dewasa dilakukan dengan menghitung IMT (Indeks Massa Tubuh). Imt adalah perbandingan berat badan dan tinggi badan kuadrat. Pada anak-anak dan remaja pengukuran IMT sangat terkait dengan umurnya, karena dengan perubahan umur terjadi perubahan komposisi tubuh dan densitas tubuh:

$$
\text { Rumus : } \frac{\text { Berat Badan }(\mathrm{Kg})}{\text { Tinggi Badan }(\mathrm{m})^{2}}
$$

Tabel 3. Norma Indeks Masa Tubuh (IMT)/BMI

\begin{tabular}{lcll} 
& & $\begin{array}{l}\text { Disease Riska Relative to } \\
\text { Normal Weight and Waist } \\
\text { Circumference: Men }<102 \mathrm{~cm} ; \\
\text { Women }<88 \mathrm{~cm}\end{array}$ & $\begin{array}{l}\text { Men }>102 \mathrm{~cm} ; \\
\text { Women }>88 \mathrm{~cm}\end{array}$ \\
\hline Underweight & \multicolumn{1}{c}{ BMI $\left(\mathrm{kg} \cdot \mathrm{m}^{-2}\right)$} & - & - \\
\hline Normal & 18.5 & - & - \\
\hline Overweight & $25.5-24.9$ & Increased & High \\
\hline I & $30.0-29.9$ & High & Very high \\
\hline II & $35.0-34.9$ & Very high & Very high \\
\hline III & $\geq 40$ & Extremely high & Extremely high \\
\hline
\end{tabular}

Sumber: ACSM's resources for the personal trainer 3rd edition, 2010

\section{Pembahasan}

Berdasarkan analisis deskriptif frekuensi dalam pengujian hipotesis perlu dikaji lebih lanjut dengan memberikan interpretasi keterkaitan antara hasil analisis yang dicapai dengan teori-teori yang mendasari penelitian ini. Penjelasan ini diperlukan agar dapat diketahui kesesuaian teori-teori yang dikemukakan dengan hasil penelitian yang diperoleh.

Hasil penelitian yang dikemukakan adalah sebagai berikut (1) status gizi siswa SMPN 1 Marioriawa dalam kategori normal karena kategori ambang batas IMT > 18,5 - 24,9 sebesar 100\% atau seluruh sampel yang terdapat dalam penelitian ini dalam kategori ambang normal, dan (2) kesegaran jasmani siswa 
SMPN 1 Marioriawa dalam kategori baik hal ini dibuktikan dari hasil analisis deskriptif frekuensi diketahui ada dari 30 sampel diketahui ada 2 sampel berada pada kategori baik sekali atau pada interval nilai 22 - 25 memperoleh nilai presentase sebesar 6,67\%, 14 sampel berada pada kategori baik atau pada interval nila 18 - 21 memperoleh nilai presentase sebesar 46,67, 13 sampel berada pada kategori sedang atau pada interval nila 14 - 17 memperoleh nilai presentase sebesar 43,33\%, 1 sampel berada pada kategori kurang atau pada interval nila 10 - 13 memperoleh nilai presentase sebesar 3,33\% dan tidak ada sampel berada pada kategori kurang sekali atau pada interval nilai 5 - 9. Dengan dapat disimpulkan bahwa hasil interval nilai sedang memperoleh nilai tertinggi hal ini dapat diartikan bahwa kebugaran jasmani siswa SMPN 1 Marioriawa sedang atau sebesar $46,67 \%$.

Status gizi dan tingkat kesegaran jasmani menjadi faktor penentu di berbagai cabang olahraga dan sebagainya. Menghubungkan teori di atas dengan hasil penelitian ini maka sangat jelas bahwa tingkat kesegaran jasmani memiliki korelasi dengan status siswa SMPN 1 Marioriawa.

Status gizi merupakan ekspresi dari keadaan keseimbangan dalam bentuk variabel tertentu atau dapat dikatakan bahwa status gizi merupakan indikator baik buruknya penyediaan makanan sehari-hari. Baik buruknya gizi seseorang sangat bergantung pada kualitas dan kuantitas makanan yang dimakan, dalam hal ini gizi sangat berpengaruh dalam kesehatan jasmani. Jika seseorang mempunyai status gizi yang buruk maka kesehatan jasmaninya juga akan buruk begitu juga dengan kesegaran jasmaninya. Dari beberapa pendapat di atas penulis menyimpulkan tentang status gizi, status gizi adalah ekspresi dari keadaan keseimbangan dalam bentuk nilai tertentu atau dapat dikatakan bahwa status gizi merupakan indikator baik buruknya penyedian makanan sehari-hari. Status gizi yang baik diperlukan untuk mempertahankan derajat kebugaran dan kesehatan, membantu pertumbuhan bagi pertumbuhan manusia serta menunjang perestasi olahraga.

Tingkat kesegaran jasmani merupakan kekuatan potensial yang ada di dalam diri seorang manusia, yang dapat dikebangkannya sendiri atau dikembangkan oleh sejumlah kekuatan luar yang pada intinya berkisar sekitar imbalan moneter dan imbalan nonmoneter, yang dapat mempengaruhi hasil kerjanya secara positif atau secara positif, hal mana tergantung pada situasi dan kondisi yang dihadapi orang bersangkutan.

Selanjutnya kehidupan di era modernisasi penuh dengan tantangan, di antaranya ancaman terhadap kualitas hidup yang berhubungan dengan kesehatan manusia. Masyarakat di negara maju sudah merasakan rangkaian akibat dari gaya hidup yang lebih banyak diam, kurang bergerak dan kelebihan kalori sebagai dampak dari otomatisasi dan kelebihan kalori. Cepat atau lambat sekarang mulai terasa masyarakat Indonesia sudah mulai menjalani gaya hidup diam, terutama dikalangan lapisan menengah keatas. Akibat yang dirasakanya itu adalah meningkatnya penyakit hipokinetik (kurang gerak), akibat langsung adalah rendahnya kemampuan dan tingginya angka sakit yang tentunya juga berdampak terhadap kesegaran jasmani seseorang.

PJKR_

http://jurnal.unimed.ac.id/2012/index.php/jpehr/index 


\section{Simpulan}

Dari hasil pengujian hipotesis dan pembahasan hasil penelitian, dapat ditarik kesimpulan sebagai berikut: 1) status gizi siswa SMPN 1 Marioriawa dalam kategori normal karena kategori ambang batas IMT > 18,5 - 25,00 sebesar $100 \%$ 2) kebugaran jasmani siswa SMPN 1 Marioriawa dalam kategori baik atau sebesar $46,67 \%$.

\section{Rujukan}

Ateng, Abdul Kadir, 1992. Azas-azas dan landasan pendidikan jasmani: Jakarta, Direktorat Jenderal Pendidikan Tinggi Proyek Tenagan Pendidikan.

ACSM, 2010. ACSM's resources for the personal trainer 3rd edition, Philadelphia: Lippincott Williams \& Wilkins.

Departemen Kesehatan RI, 1994. Pedoman Pengukuran Kesegaran Jasmani. Jakarta: Depkes RI.

Halim, Nur Ichsan, 2011. Tes dan Pengukuran Dalam Bidang Keolahragaan. Makassar: Badan Penerbit UNM Makassar.

Harsono, 1988. Coaching dan Aspek-aspek Psikologis dalam Coaching. CV. Tombuk Lasuma.

Halim, Nur Ichsan. 2011. Tes dan Pengukuran Kesegaran Jasmani. Makasar: Badan Penerbit Universitas Negeri Makassar.

Irianto Djoko Pekik, 2006. Panduan Gizi Lengkap Keluarga dan Olahragawan. Yogyakarta: Penerbit CV. Andi Offset.

Sajoto, 1988. Peningkatan dan Pembinaan Kekuatan Kondisi Fisik. Semarang: Dahara Prize.

Nurhasan, 2001. Tes dan Pengukuran dalam Pendidikan Jasmani. Jakarta: Penerbit Direktoral Jenderal Olahraga.

Suhardjo, 1996. Gizi Dan Pangan. Yokyakarta: Kanisius.

Supariasa I Dewa Nyoman, 2001. Penilaian Status Gizi. Jakarta: Penerbit Buku Kedokteran EGC.

Wahjoedi, 2000. Landasan Evaluasi Pendidikan Jasmani. Jakarta: PT. Grafindo Persada. 